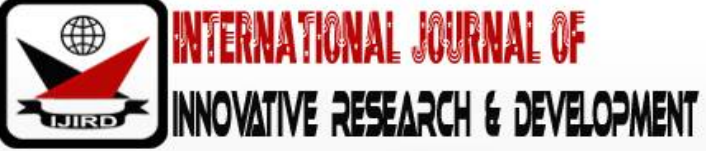

ISSN 2278 - 0211 (Online)

\section{Generating Creativity for National Development through Biology Education: A Study of Biology Students' Perception at Colleges of Education in Oyo Town, Oyo State, Nigeria.}

\author{
Araoye, Martina Ivie \\ Principal Lecturer, Department Of Biology, School of Secondary Education (Science Programmes) \\ Federal College of Education (Special), Oyo, Nigeria
}

\begin{abstract}
:
This paper examines Students perception of biology education as an enhancer of creativity for National Development. The study employed a descriptive survey design and employed the NCE 1 and II levels biology students of the Federal College of Education (Special) and Emmanuel Alayande College of Education, both in Oyo, Oyo State. Nigeria. A population of one hundred (100) biology students were sampled and used for the study through simple random sampling techniques. The four point scale Likert- type questionnaire was adapted as the research instrument for the study. The questionnaire was made up of two sections namely section A and B. Section A was concerned with the demographic profile of the respondents while section B contained 20 structured items based on the topic. The face validated questionnaires were administered under strict monitoring for data integrity. Data collected were analyzed using Descriptive and Inferential statistics. The findings indicated that the students perceived that qualitative teaching of biology education to interested learners fosters their creative thinking and that teachers' effective application of appropriate methodology and knowledge of biological concepts promotes students' creative ability. All this have consequence for national development. However, the students' level did not affect their respective views. Based on the above submissions, recommendations were made.
\end{abstract}

Keywords: Biology education, creativity, national development, students' perception, methodology, biological concepts

\section{Background of the Study}

Biology is a standard subject of instruction at all levels of the Nigerian Educational System. As a discipline, it is quite popular among school children, from pre-primary to tertiary levels. Biological knowledge is devoid of superstition, emotion and sentiment. It is the rational procedure for aiming at the truth. Similarly, biology exposure enhances mental and physical skill acquisitions, innovations and competencies which equip a willing learner for positive contribution to social and economic development of the nation.

Ukpai and Awoke (2010) stated that, for a nation to produce students that would be able to acquire the necessary knowledge, skills and competencies needed to meet the present trend of development drive with the concomitant scientific and technological demands, the need for scientific literacy becomes paramount. Biology is one of those science subjects therefore that an individual need to be exposed to, in order for him/ her to be useful to the society. It becomes necessary therefore that the right teaching methodology be used to effectively communicate the diverse aspects of biology as a subject. The different methodologies and teaching strategies being employed include lecture, demonstration, guided inquiry, discovery concept, mapping, project, acting method, discussion, practical approaches and many others.

Biology Education from the foregoing, serves both individual and social roles through inculcating knowledge and right types of attitudes for the survival of both the individual and society at large (Georgwill, 2006 cited in Araoye, 2016).

Biological sciences generate continuous innovations (technological, organizational, managerial) through learning entities that have been shown to be responsible not only for productivity increases, but also for dynamic competitive advantages of firms, industries and nations in the unfolding global economy. Biology is more than a body of knowledge; it is also a dynamic field of human endeavour, rich in reward to the individual and containing many creative aspects. As a result, the teaching and learning of biology produces excellent outcome.

As put by Diki (2013), biology students must be trained to think, describe and evaluate concepts, therefore, they need to think creatively, to enable them evaluate ideas and produce solutions for actual problems. Thus, he suggested skills of creativity to include defining problems, analogies, proposing treatment of unexpected results, and testing hypothesis. This mostly covers the classroom activities, online learning and laboratory practices.

A willing learner in the biology classroom must be taught to acquire both proficiency and creativity. Creativity is important in learning biology and for productivity. This however can be achieved through the right choice and application of the teachers' methodologies. According to Guilford (1950) cited in Diki (2013), education should not focus on memorizing information, but should focus on how to use the information for solving problems. 
Laboratory practices are an integral and acceptable part of teaching biology where students are made to practice problem solving on their own and so students' involvement in such activities not only develop process skills but also promotes individual interest, creativity and enhance good performance in the subject matter.

According to Olagunju (2009), creativity in science education requires that the teacher should evolve new approaches to teaching in order to initiate better results in the teaching of scientific concepts. The biology teacher has a variety of teaching methods and strategies to navigate with to help his teaching and make good outcome. A good biology teacher should enhance his choice of teaching method using supporting materials like model, graph, video, posters, charts and other laboratory activities. Where these are not available, students should be taught to help with improvisation. A combination of activity- based methods will enhance creativity in the learner as this enables students to do more of thinking, experimenting and solving human problems while the teacher serves as facilitator. Teaching and learning that is student-centered activity oriented and not too much of teacher-driven will of course boost students' interest.

\subsection{Creativity and Biology Education}

Creativity is the quality or ability to create or invent something. As defined by Diki (2013), creativity is the formation of new and useful ways to solve a problem. Qualitative biology education breeds and sustains creativity. As inferred by Fakayode (2005), creativity in learning is the learners' ability to accumulate, synthesize and apply the knowledge gained in various aspects of life. This is made possible under biology education as students are exposed to learning experiences outside the classroom and laboratories through visits to building sites, factories, workshops, natural scenes like mountains, rivers, etc.

Creativity is often viewed as reactive, that is, a reaction to problems or challenges. It is the development of original ideas that are useful or influential, not just a reaction therefore, but also a contribution to change and evolution (Runco, 2004). Creativity is what the world needs today. For developing nations to be able to cope with the present-day development and technological drive, creativity is the key.

Teaching and learning of biology inculcate in students, scientific attitudes and values as well as scientific processes of observation, measurement and classification. The biology curriculum aims broadly at developing in a learner, scientific methods such as defining a problem, observation, hypothesis, experimentation, analyzing, predicting, recording, etc. which are all life coping skills that can foster creativity.

Manpower development is made possible through the practice of skills, experience and educational acquisition required by the labour force for quick and sustainable development of a nation (Aiworo, Nosakhare and Osemwenkha, 2009 in Ogunloye, Obadipe and Edegbai, 2019). This is amplified by Jeronen, Palmberg and Yli -Panula (2017) quoting Asyari, Nuhdhar and Ibrahim (2016), who stated that implementation of problem-based learning and group investigation, encourages students to think critically through planning, arguing, stating questions and problems and providing solutions to environmental problems. These are what biology education offers and by implication promote the development of the totality of man and the natural world.

Creativity can be enhanced through the following biology teaching methods and techniques:

Proposing treatment of unexpected result: Often times in practical classes at F.C.E. (Sp) Oyo, biology students through the use of the Practical Manual, are exposed to finding out solutions to stated problems. This, they do either through microscopic examinations or observation of experimental processes. Over time, these activities have enhanced creativity among the students. According to Mumford (2010) cited by Diki (2013), those unexpected findings, like any result of an experiment that is different from what was expected, may lead to new alternatives to solving a certain problem. This method thus stands out as one that can be applied in the educational setting as it provides opportunity for students to discover different and novel ways to solving identified problems.

Teacher's choice of method:

- Project Method: This is a medium of instruction in studying biology which enables students apply the skills and knowledge they had learned in the course of their studies to problems they had to solve as practitioners in their fields. It is a non-paper based note-memorization or teacher-led classroom setting. It is research-oriented and thus gives the students the opportunity to explore problems and challenges that have real-world application thereby increasing the possibility of long-term retention of skills, concepts and above all, motivates creativity. As put by McCabe (2011), most researchers tend to seek only the findings that support the idea. Meanwhile, they tend to put less attention towards unexpected findings (negative results). There are two possible actions of a researcher who find the unexpected result, whether to follow the unexpected or ignore it. However, for a student exposure to a biological research, project or writing which could be either experimental or survey with a creative mind set, the investigation of the unexpected result must be focused on three categories of research result which are expected, unexpected and exploratory results. Indeed, it takes the skill of creativity and positive reasoning for the researcher to pay significant attention to the unexpected and try to elaborate the cause of the finding.

- Demonstration Method: One of the two most essential teaching skills is the ability to demonstrate. The other is the ability to explain. Demonstration is any planned performance of an occupation skill, scientific principle or experiment. Students' exposure to this method can get better in drawing. As put by Runco (2004), creative activities can challenge the most able, giving them the freedom to develop and immerse themselves in a topic as well as encouraging independent learning. Gifted and Talented students often face the problem of simply being given extension work or more challenging questions. Using creativity can allow a different type of extension- not simply by giving them more to read or learn, but instead an opportunity to extend their understanding in a topic they find interesting, where skills are enhanced too. 
Correct application of certain teaching methods or techniques, for example, project method, questioning, demonstration and other activity-based methods shows that creativity of students can be improved during studying biology and by implication, promote national development.

\subsection{Creativity and National Development}

Creativity is not however, just a concern and target for individuals, its benefits are just as clear for society and culture (Simonton, 1991) cited by Runco (2004). According to Dudek (2003), creativity plays an important role in technological advances, in the social and behavioural sciences and in the humanities and arts. It plays important role in innovation and entrepreneurship. It has become one of the key concerns of organizations and businesses. Also, creativity contributes to both physical and psychological health and optimal functioning (Runco \& Richards, 1997; Runco, 2004).

Creativity is an essential tool for development. As opined by Oyeniyi (2019), creativity is no longer something that is destructive. It has now become a necessary and fundamental requirement for the achievement of a person, organization or country. Creativity is not only subject to the innovation but covers all acts and thoughts. The present challenging world of learning in global economic climate is more concerned with innovation and creativity.

According to Economy of Culture (2006), cited by Ogunleye, Obadipe and Edegbai (2019), creativity is considered as one of the bases of economic and social progress of any society. In similar view, Ogunleye, Obadipe and Edegbai (2019), referring to Sabadie and Johansen (2010), stated that it is not the abundance of natural resources and market size of a country that make her a developed nation but opening to new ideas and brightest minds to improve the standard of living of the people. Less prosperous or poor countries can significantly improve greatly by gearing all efforts on innovation to raise the quality of education and increase access to education and training.

\subsection{Statement of the Problem}

Developing nations like Nigeria are faced with diverse developmental problems such as lack of self-reliant capabilities, citizenry skills, innovations and technological improvement and so on. Education plays a very paramount role in national building. However, education for mere certificate acquisition and non-possession of appropriate skills without taking into consideration developmental, technological and social challenges would jeopardize the future. Biological knowledge is intrinsically related to building a sustainable economy and promotion of national development. Biology and biology education have advanced rapidly in the last decades. The present bio-century is making conscious efforts for social impact, economic and sustainability development as well as meeting other environmental challenges. Despite these, most students of biology run through the course of study without proper understanding of its role in nation building. This paper therefore examines creativity for national development: a study of biology students' perception at the Federal College of Education (Sp.) and Emmanuel Alayande College of Education, Oyo.

\subsection{Purpose of the Study}

The purpose of this study is to enhance better students' performance, better conceptualization of biological concepts, problem solving ability and promotion of creativity and thus, national development.

\subsection{Research Questions}

The following questions guided the study:

Does Students' exposure to biology education foster creative thinking?

Do biology students perceive that effective use of biology teaching methods and their knowledge of biological concepts inspire creativity?

Do biology students perceive that right application of creative thinking has consequence for national development?

\subsection{Hypotheses}

The following null hypotheses were formulated and tested at 0.05 level of significance:

- $\mathrm{HO}_{1}$. Students' exposure to biology education is independent of creative thinking.

- $\mathrm{HO}_{2}$. Students' perception of correct methodology and general knowledge of biological concepts is

- independent of creativity.

- $\mathrm{HO}_{3}$. Students' perception of biology education and creativity is independent of National

- Development.

\section{Methodology}

Research Design: The study employed a descriptive survey design. Population of the Study: The study targeted the biology students of both Federal College of Education (Sp.), and Emmanuel Alayande College of Education, Oyo. However, only the NCE 1 and NCE II students were employed in the study.

Sample and Sample Techniques: A hundred (100) biology students were sampled and used for the study through simple random sampling techniques.

Research Instrument: A structured questionnaire was adapted as the research instrument for the study. The questionnaire was made up of two sections namely section A and B. Section A was concerned with the demographic profile of the respondents while section B contained 20 structured items based on research topic. It was designed to elicit respondents' opinion on the various questions covering the research area. Responses were provided based on the fourpoint Likert-type of Strongly Agree (SA), Agree (A), Disagree (D), and Strongly Disagree (SD). The face validated 
questionnaire was administered under strict monitoring data collected were analysed using descriptive and inferential statistics.

\section{Results}

Frequency Tables:

\begin{tabular}{|c|c|c|c|c|c|}
\hline \multicolumn{6}{|c|}{ Gender of Respondents } \\
\hline \multicolumn{2}{|c|}{} & $\begin{array}{c}\text { Frequenc } \\
\mathrm{y}\end{array}$ & Percent & $\begin{array}{c}\text { Valid } \\
\text { Percent }\end{array}$ & $\begin{array}{c}\text { Cumulative } \\
\text { Percent }\end{array}$ \\
\hline \multirow{2}{*}{$\begin{array}{c}\text { Vali } \\
\text { d }\end{array}$} & Male & 16 & 16.0 & 16.0 & 16.0 \\
\cline { 2 - 6 } & Female & 84 & 84.0 & 84.0 & 100.0 \\
\cline { 2 - 6 } & Total & 100 & 100.0 & 100.0 & \\
\hline
\end{tabular}

Table 1: Gender of Respondents

From the total of 100 respondents 16 (16\%) are males while the remaining 84 (84\%) are females

\begin{tabular}{|c|c|c|c|c|c|}
\hline \multicolumn{5}{|c|}{ Level of Respondents } \\
\hline \multicolumn{2}{|c|}{} & $\begin{array}{c}\text { Frequenc } \\
\mathrm{y}\end{array}$ & Percent & $\begin{array}{c}\text { Valid } \\
\text { Percent }\end{array}$ & $\begin{array}{c}\text { Cumulative } \\
\text { Percent }\end{array}$ \\
\hline \multirow{3}{*}{$\begin{array}{c}\text { Vali } \\
\mathrm{d}\end{array}$} & NCE I & 49 & 49.0 & 49.0 & 49.0 \\
\cline { 2 - 6 } & NCE II & 49 & 49.0 & 49.0 & 98.0 \\
\cline { 2 - 6 } & NCE III & 2 & 2.0 & 2.0 & 100.0 \\
\cline { 2 - 6 } & & & & & \\
\cline { 2 - 6 } & Total & 100 & 100.0 & 100.0 & \\
\hline
\end{tabular}

Table 2: Level of Respondents

$49(49 \%)$ of the respondents are in part 1, 49(49\%) are in part II, $1(2 \%)$ are in part III. This indicates that students' level did not affect their perception of biology education, creativity and National Development.

\subsection{Inferential Statistics}

\subsubsection{Hypothesis 1}

- $\mathrm{H}_{0}$ : Students' exposure to biology education is independent of creative thinking.

- $\mathrm{H}_{1}$ : Student' exposure to biology education is dependent on creative thinking.

\begin{tabular}{|c|c|c|c|}
\hline \multicolumn{4}{|c|}{ Chi-Square Tests } \\
\hline & Value & Df & $\begin{array}{c}\text { Asymp. Sig. } \\
(2 \text {-sided })\end{array}$ \\
\hline Pearson Chi-Square & $15.629 \mathrm{a}$ & 6 & .016 \\
\hline Likelihood Ratio & 9.478 & 6 & .148 \\
\hline $\begin{array}{c}\text { Linear-by-Linear } \\
\text { Association }\end{array}$ & 3.715 & 1 & .054 \\
\hline N of Valid Cases & 100 & & \\
\hline
\end{tabular}

Table 3: Chi-Square Tests

a. 8 Cells (66.7\%) Have Expected Count Less Than 5

The Minimum Expected Count Is .10

\subsubsection{Decision}

Since the Pearson Chi-Square value of 15.629 is greater than the tabulated value of chi-square at 6 degrees of freedom and the asymptotic significance (2-sided) value of 0.016 is less than alpha value of 0.05 , the null hypothesis was therefore rejected. It is therefore concluded that Students' exposure to biology education is dependent of creative thinking and vice versa. This therefore means that qualitative teaching of biology education to interested learners fosters their creative thinking.

\subsubsection{Hypothesis 2}

- $\mathrm{H}_{0}$ : Students' Perception of correct methodology and knowledge of biological concepts is independent of creativity.

- $\mathrm{H}_{1}$ : Students' Perception of correct methodology and knowledge of biological concepts is dependent of creativity. 


\begin{tabular}{|c|c|c|c|}
\hline \multicolumn{4}{|c|}{ Chi-Square Tests } \\
\hline & Value & Df & Asymp. Sig. (2-sided) \\
\hline Pearson Chi-Square & $9.872^{\mathrm{a}}$ & 4 & .043 \\
\hline Likelihood Ratio & 9.393 & 4 & .052 \\
\hline Linear-by-Linear Association & 2.373 & 1 & .123 \\
\hline N of Valid Cases & 100 & & \\
\hline
\end{tabular}

Table 4: Chi-Square Tests

a. 5 Cells (55.6\%) Have Expected Count Less Than 5

The Minimum Expected Count Is .54

\subsubsection{Decision}

Since the Pearson Chi-Square value of 9.872 is greater than the tabulated value of chi-square at 4 degrees of freedom and the asymptotic significance (2-sided) value of 0.043 is less than alpha value of 0.05 , the null hypothesis was therefore rejected for the alternative hypothesis. It was therefore concluded that correct Methodology and knowledge of biological concepts is dependent of Creativity and vice versa. This implies that biology students perceived teacher's effective application of appropriate methodology and knowledge of biological concepts as enhancers of students' creative ability.

\subsubsection{Hypothesis 3}

- $\mathrm{H}_{0}$ : Students' perception of biology education is independent of Creativity and National development.

- $\mathrm{H}_{1}$ : Students' perception of biology education is dependent of Creativity and National development

\begin{tabular}{|c|c|c|c|}
\hline \multicolumn{4}{|c|}{ Chi-Square Tests } \\
\hline & Value & Df & Asymp. Sig. (2-sided) \\
\hline Pearson Chi-Square & $16.023^{\mathrm{a}}$ & 4 & .003 \\
\hline Likelihood Ratio & 15.884 & 4 & .003 \\
\hline $\begin{array}{c}\text { Linear-by-Linear } \\
\text { Association }\end{array}$ & .000 & 1 & 1.000 \\
\hline N of Valid Cases & 100 & & \\
\hline
\end{tabular}

Table 5: Creativity and National Development

a. 2 Cells (22.2\%) Have Expected Count Less Than 5

The Minimum Expected Count Is 1.44

\subsubsection{Decision}

Since the Pearson Chi-Square value of 16.023 is greater than the tabulated value of chi-square at 4 degrees of freedom and the asymptotic significance (2-sided) value of 0.003 is less than alpha value of 0.05 , the null hypothesis is therefore rejected. It was therefore concluded that students' perception of biology education is dependent of creativity and National development and vice versa. This simply means biology students perceived that the teaching of biology can enhance creativity which when rightly applied will boost national development.

\section{Conclusion}

Every day, the world grows technologically and only a creative mind can cope. Students and school leavers must be encouraged to be intentionally creative to prepare them for the future. Creativity is an essential tool for development. Biology students' exposure to proper use of teaching methodologies and learning opportunities enhance mental and physical skill acquisitions, innovations and competencies which thus equip a willing learner for contribution to social and economic development. Therefore, correct application of biology teaching methods or techniques, for example, project method, questioning, demonstration and other activity-based methods foster creative thinking in the learners and by implication, national development.

\section{Recommendations}

From the findings of this study, the following are therefore recommended:

- All biological concepts must be well taught with proper methodologies to motivate students' creativity.

- Teaching methodologies in the sciences and especially biology should be activity and student-centred giving room for much out-door content.

- Teachers must be creative themselves. Various training opportunities for empowerment in this respect should be provided by institutions and government.

- Government must provide the enabling environment and make available to schools supporting materials for teaching and learning biology.

- Various incentives including some forms of scholarships should be provided for students who show much creativity in the study of biology education as a way of motivating students to be their best at school. 


\section{References}

i. Araoye, M.I. (2016). Biology Education and National Productivity: Implication for Transforming Nigerian Educational System. International Journal of Advanced Academic Research, Arts, Humanities \& Education. 2(7):1-6

ii. Diki, D. (2013). Creativity for Learning Biology in Higher Education. Lux: A Journal of Tran disciplinary Writing and Research. 3 (1): 1-13.

iii. Fakayode, S.A. (2005). Teaching for Creativity: The Gap in Curriculum Implementation. In Dada, A., Abimbola \& Kolawole, U.O. (Eds) Issues in Language Communication and Education: A Book of Reading in honour of Caroline A. Okedara (pp. 455-465). Ibadan, Nigeria: Constellation Books.

iv. Jeronen, E., Palmberg, I. \& Yli-Panula, E. (2017). Teaching Methods in Biology Education and Sustainability Education Including Outdoor Education for Promoting Sustainability. A Literature Review. Education Sciences 7 (1), 1-19.

v. McCabe, B. (2011). An Integrated Approach to the Use of Complementary Visual Learning Tools in an Undergraduate Microbiology Class Education. Journal of biological Education 45(4), 236-243.

vi. Ogunleye, A.T., Obadipe, J.A. \& Edegbai, A.B (2019). Science Education for Creativity and Economic Development in an Evolving Democratic System. A paper presented at the School of Science 13th National Conference. Federal College of Education, Osiele, Abeokuta. 1st -5th, April. 1-10.

vii. Olagunju, A.M. (2007). Science Education for the Emancipation of a Recessed Economy in the 21st Century. A Lead Paper presented at the $3^{\text {rd }}$ National Conference of the School of Science, Federal College of Education (Special), Oyo held on $11^{\text {th }}$ March.

viii. Oyeniyi, A.O. (2019). Science Education for Creativity and Economic Development: Effects of Guided Inquiry Mehods on Students' Achievement in Basic Science in Junior Secondary School, Ekiti State Nigeria. A paper presented at the School of Science 13th National Conference. Federal College of Education, Osiele, Abeokuta. 1 ${ }^{\text {st }}$-5th, April. 1-14.

ix. Robert, W.M. (1960). Creativity, Biology and Education. AIBS Bulletin

x. Runco, M.A. (2004). Creativity. Annual Review of Psychology, 55, 657-687. doi: 10.1146/ annurev.psych.55.090902.141502 (Retrieved 28/ 03/ 19).

xi. Ukpai, P.O. and Awoke, J.S. (2010). Practical Approach to Effective Teaching of the Nervous System in Secondary Schools. In Nwagbo, C.R and Uzewi, U.M. (Eds). Practical Approach to Effective Teaching of the Nervous System. STAN, Biology Panel Series. 62-70. Timex Enterprises. 